\title{
PARTISIPASI DALAM PENCEGAHAN DAN PENANGGULANGAN COVID-19
}

DOI: https://doi.org/10.33024/jkpm.v4i4.4042

\author{
Dyan Kunthi Nugrahaeni ${ }^{*}$, Novie Elvinawaty Mauliku², Budiman ${ }^{3}$, Gunawan \\ Irianto ${ }^{4}$, Arina Novilla ${ }^{5}$ \\ ${ }^{1-4}$ Program Studi Kesehatan Masyarakat, Stikes Jenderal Achmad Yani Cimahi \\ ${ }^{5}$ Program Studi D3 Teknologi Laboratorium Medis, Stikes Jenderal Achmad Yani \\ Cimahi
}

Disubmit: 15 Maret 2021 Diterima: 07 April 2021 Diterbitkan: 04 Agustus 2021

Email Korespondensi: dyankunthi@yahoo.co.id

\begin{abstract}
ABSTRAK
The World Health Organization menetapkan outbreak SARS-CoV-2 sebagai Kedaruratan Kesehatan Masyarakat yang Meresahkan Dunia dan dinyatakan sebagai pandemik. Penyebaran dan penularan penyakit Coronavirus Disease-19 (COVID-19) sangat tinggi, dengan jumlah penderita lebih dari 117 juta di seluruh dunia. Diperlukan berbagai strategi dan tindakan yang dapat dilakukan untuk pencegahan, penanggulangan dalam rangka mengatasi COVID-19. Tujuan Pengabdian masyarakat yang dilakukan oleh Stikes Achmad Yani adalah ikut berperan serta dalam pencegahan dan penanggulangan COVID-19 di wilayah Kota Cimahi dan Kota Bandung. Metode yang digunakan adalah partisipatori dalam berbagai aktifias pencegahan dan penanggulangan COVID-19. Kegiatan Pengabdian Masyarakat yang dilakukan selama pandemic COVID-19 diantaranya adalah demontrasi pembuatan handsanitizer, penyemprotan disinfektan, mengirimkan tim relawan pemeriksaan Rapid Diagnostic Test (RDT) antibodi Cluster Lembang dan relawan Check Point pada kegiatan Pembatasan Sosial Berskala Besar di Kota Bandung. Pemberian donasi kepada masyarakat terdampak pandemik COVID-19 dan donasi Alat Pelindung Diri (APD) ke fasilitas pelayanan kesehatan seperti Rumah Sakit dan Puskesmas. Pelaksanaan Rapid Test Diagnostic (RTD) antibodi dan RTD antigen bagi mahasiswa, dosen dan Karyawan. Stikes Achmad Yani juga berperan serta dalam gebyar Vaksin COVID-19 bagi tenaga kesehatan dan mengirimkan relawan sebagai vaksinator yang diselenggarakan oleh Rumah Sakit Hasan Sadikin berkerjasama dengan PPNI. Partisipasi Stikes Achmad Yani Cimahi dalam berbagai kegiatan yang terkait dengan COVID-19 diharapkan dapat memberikan kontribusi dalam rangka pencegahan penularan, pengendalian dan penanggulangan COVID-19.
\end{abstract}

Kata Kunci: COVID-19, disinfeksi, relawan, Rapid Diagnostic Test 


\begin{abstract}
The World Health Organization recognize SARS-CoV-2 outbreak as a public health emergency of Internasional Concerns and declared it as pandemic. The spread and transmission of Coronavirus Disease-19 (COVID-19) is very high and reported that over 117 million people have been sufferers worldwide. Several strategies and actions that can carried out to prevention, controlling and overcoming COVID-19. The purpose of community service carried out by Stikes Achmad Yani is to participate in the prevention and control of COVID-19 in Cimahi and Bandung district. The methode used in community services are participatory methods in several activities for prevention and control of COVID-19. Community Service activities carried out during the COVID-19 pandemic included demonstrations of making handsanitizers, spraying disinfectants, sending a team of volunteers to examine the Rapid Diagnostic Test (RDT) antibody for the Lembang Cluster and volunteer Check Points at Large-Scale Social Restrictions activities in Bandung. Providing donations to people affected by the COVID-19 pandemic and donations of Personal Protective Equipment (PPE) to health service facilities such as hospitals and health centers. Implementation of Rapid Diagnostic Test (RTD) antibody and RDT antigen for students, lecturers and staff. Stikes Achmad Yani also participated in the COVID-19 Vaccine for health workers and sent volunteers as vaccinators organized by Hasan Sadikin Hospital in collaboration with PPNI. The participation of Stikes Achmad Yani Cimahi in various activities to contribute prevention of disease transmission and controlling COVID-19.
\end{abstract}

Kata Kunci: COVID-19, disinfection, volunteer, Rapid Diagnostic Test

\title{
1. PENDAHULUAN
}

World Health Organization (WHO) China Country Office melaporkan bahwa pada tanggal 31 Desember 2019 adanya kasus pneumonia yang tidak diketahui etiologinya di Kota Wuhan, Provinsi Hubei, Cina (Tong et al., 2020). Penyebab penyakit teridentifikasi sebagai jenis baru coronavirus dengan nama Cononavirus Disease (COVID-19). COVID-19 disebabkan oleh Severe Acute Respiratory Syndrome Coronavirus 2 (SARS-CoV-2).

Penambahan jumlah kasus COVID-19 berlangsung sangat cepat dan terjadi penyebaran di berbagai negara, sehingga pada tanggal 30 Januari 2020, WHO menetapkan COVID-19 sebagai sebagai Kedaruratan Kesehatan Masyarakat Yang Meresahkan Dunia/ Public Health Emergency of International Concern (KKMMD/PHEIC). Pada tanggal 11 Maret, WHO menetapkan bahwa SAR-CoV-2 sebagai pandemik (Kementerian Kesehatan RI, 2020).

Data penderita COVID-19 sampai dengan tanggal 26 Maret 2021 telah menginfeksi sebanyak 219 negara, dengan jumlah kasus sebanyak 126.180.069 orang. Total kematian sebesar 2.769.326 dengan angka CFR (Case Fatality Rate) sebesar 3\%, dan kesembuhan sebesar 101.802. orang (97\%)(WHO, 2020).

Strategi penanggulangan COVID-19 disesuai dengan transmisi yang terjadi, yang bertujuan untuk menghentikan laju penularan dan menunda penyebaran penularan, menyediakan pelayanan kesehatan yang optimal untuk pasien, serta meminimalkan dampak pandemik COVID-19 terhadap 
sistem kesehatan, pelayanan sosial, kegiatan di bidang ekonomi dan sektor lainnya (Kementerian Kesehatan RI, 2020).

Situasi penyebaran COVID-19 sudah menjangkau seluruh wilayah di Indonesia sehingga berdampak pada aspek ekonomi, politik, sosial, budaya, pertahanan keamanan serta kesejahtaraan masyarakat Indonesia (Kementerian Kesehatan RI, 2020). Penetapan bencana nonalam yang disebabkan penyebaran COVID-19 berdampak pada meningkatnya jumlah penderita, kerugian harta benda, meluasnya cakupan wilayah yang terkena dampak bencana serta menimbulkan berbagai implikasi pada aspek sosial ekonomi yang luas di Indonesia (Keputusan Presiden RI, 2020).

Diperlukan berbagai upaya untuk menekan laju transmisi dan penularan COVID-19 dalam rangka percepatan penanganan COVID-19 melalui beberapa kegiatan diantaranya adalah Pembatasan Sosial berskala Besar (PSBB) untuk membatasi kegiatan penduduk dalam suatu wilayah, membatasi pergerakan orang dan barang untuk mencegah penyebaran COVID-19 di masyarakat (Peraturan Pemerintah RI, 2020).

Seluruh propinsi dan kabupaten/kota diharapkan melakukan identifikasi adanya kasus baru COVID-19 di wilayahnya, mengelola dan memberikan intervensi pada kasus COVID-19, serta berbagai upaya pencegahan dan penularan kasus dalam adaptasi kebiasaan baru dengan menerapkan protokol kesehatan yang ketat dalam setiap aktifitas masyarakat dan diharapakn setiap daerah menyiapkan dan merespon berbagai skenario kesehatan masyarakat (Kementerian Kesehatan RI, 2020).

Dalam rangka penanggulangan pandemik COVID-19 tidak hanya dilaksanakan dengan penerapan protokol kesehatan, tetapi juga melalui intervensi dengan vaksinasi, untuk meningkatkan kekebalan individu dan kelompok sebagai salah satu upaya pencegahan dan pengendalian COVID-19 (Dirjen Pencegahan dan Pengendalian penyakit, 2021)

\section{MASALAH, TARGET DAN LUARAN}

Penyakit COVID-19 menjadi masalah kesehatan di semua wilayah di Indonesia. Tingginya angka penularan penyakit di masyarakat akan berdampak dalam semua segi kehidupan, baik dalam bidang kesehatan, sosial-ekonomi, pendidikan, dan dalam berbagai kegiatan di masyarkat. Target dan luaran yang diharapkan dari kegiatan pengabdian masyarakat ini adalah ikut berperan serta dalam berbagai macam kegiatan dalam upaya pencegahan dan penanggulangan Pandemi COVID-19 di wilayah Kota Cimahi dan Kota Bandung. Jumlah penderita COVID-19 di Kota Cimahi sebesar 3.733, dengan tingkat kesembuhan sebesar 92,7\%, jumlah penderita aktif sebesar 4,75\% dan penderita meninggal dunia sebesar 2, 46\% (Perkembangan COVID19 di Kota Cimahi, 2020). 

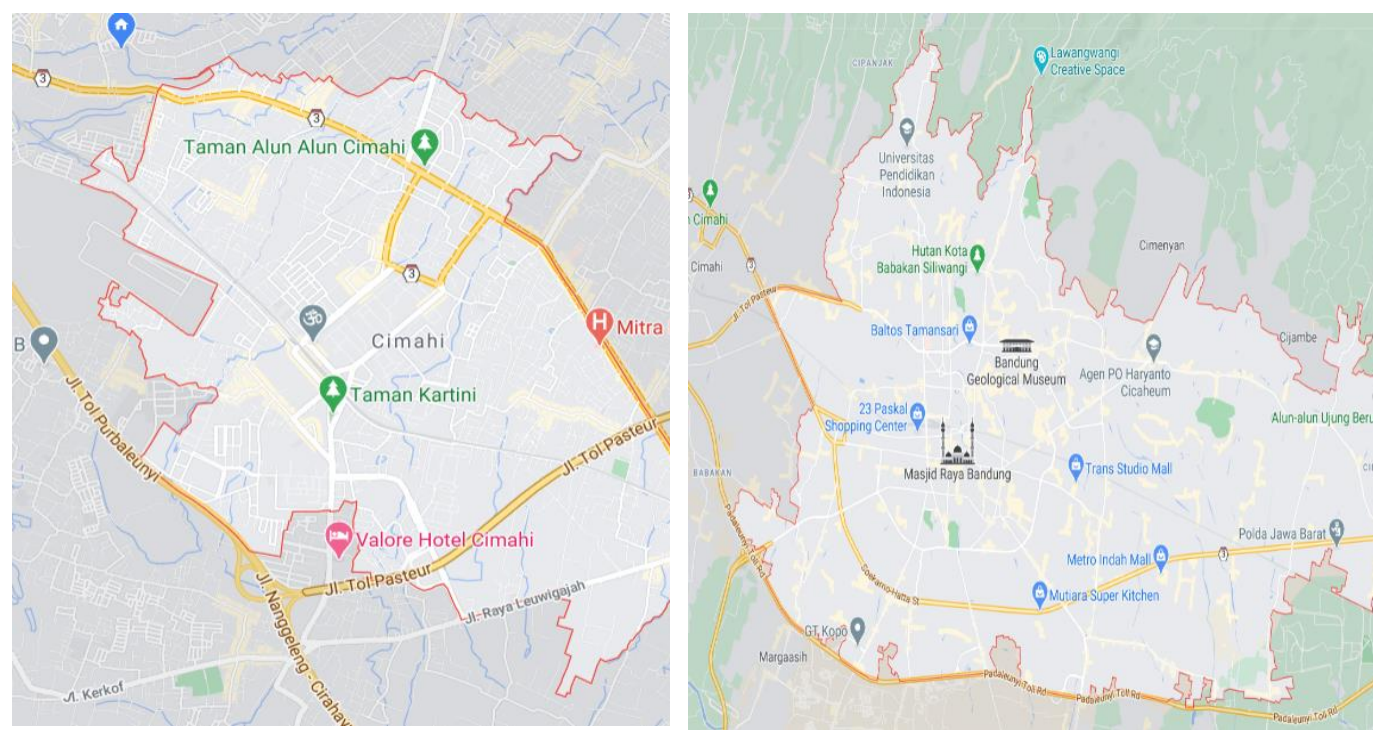

Gambar 1. Peta Lokasi Kegiatan Pengabdian Masyarakat

\section{METODE PELAKSANAAN}

Pengabdian kepada masyarakat dilaksanakan dengan metode partisipatori dalam berbagai macam kegiatan dalam rangka pencegahan dan penanggulangan COVID-19, diantaranya yaitu:

a. Demontrasi cara pembuatan handsanitizer di tingkat laboratorium.

b. Penyemprotan disinfektan di seluruh area di Stikes Jenderal Achmad Yani Cimahi secara rutin .

c. Berpartisipasi dalam pemeriksaan Rapid Diagnostic Test (RDT) antibodi COVID-19 dengan mengirimkan tim relawan Cluster Lembang Bandung.

d. Berpartisipasi dalam pelaksanaan PSBB (Pembatasan Sosial Berskala Besar di Kota Bandung) dengan mengirimkan tim relawan Check point PSBB.

e. Donasi sembako kepada masyarakat sekitar Kampus Stikes Achmad Yani Cimahi terdampak COVID-19.

f. Pemberian donasi APD (Alat Pelindung Diri) ke beberapa fasilitas pelayanan Kesehatan di wilayah Kota Cimahi dan Kota Bandung.

g. Pelaksanaan Rapid Test Diagnostic (RTD) antibodi dan Rapid Test Diagnostic (RTD) antigen kepada mahasiswa, Dosen dan karyawan Stikes Jenderal Achmad Yani Cimahi.

h. Pelaksanaan vaksinasi bagi tenaga kesehatan dan pengiriman relawan vaskinator dalam gebyar Vaksin COVID-19 di Jawa Barat.

\section{HASIL PEMBAHASAN}

Hasil pelaksanaan pengabdian kepada masyarakat yaitu partisipasi Stikes Jenderal Achmad Yani Cimahi dalam pencegahan dan penanggulangan COVID-19 adalah sebagai berikut:

\section{a. Demonstrasi pembuatan handsanitizer}

Demonstasi pembuatan cairan handsanitizer dilaksanakan di Laboratorium Program Studi TLM (Teknologi Laboratorium Medik) Stikes Jenderal Achmad Yani berupa Video dan di upload di Channel Youtube Stikes Jenderal Achmad Yani, sehingga dapat di jadikan salah satu rujukan bagaimana membuat handsanitizer oleh seluruh sivitas akademika dan masyarakat secara luas. 
Handsanitizer yang sudah dibuat oleh tim Satuan Tugas Pencegahan dan Penanggulangan COVID-19 dibagikan kepada seluruh karyawan Stikes Jenderal Achmad Yani Cimahi dan Masyarakat sekitar kampus.

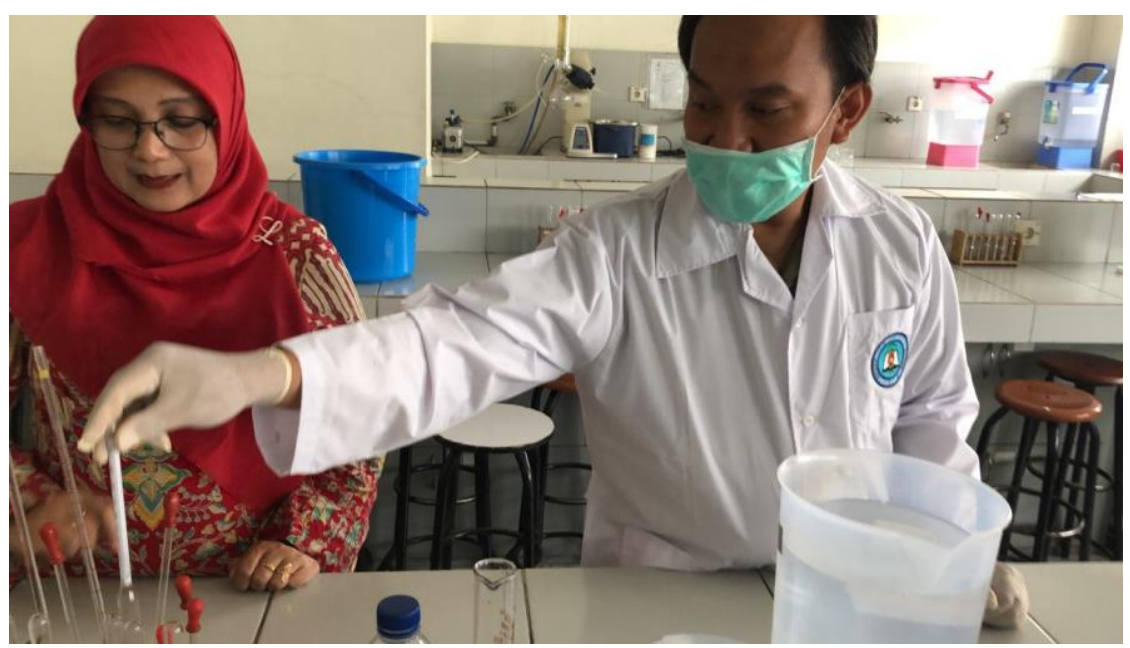

Gambar 2. Pembuatan Handsanitizer

Video mengenai pembuatan Handsanitizer dapat di lihat pada link berikut: https://www.youtube.com/watch?v=q6XZ_Ug_q0U

\section{b. Penyemprotan Disinfektan di Seluruh Area Kampus Secara Periodik}

Penyemprotan disinfektan di seluruh area kampus Stikes Jenderal achmad Yani Cimahi dilakukan secara periodik. Pelaksanaan penyemprotan disinfektan di Stikes Achmad Yani Cimahi sesuai dengan panduan dari Kementerian Kesehatan di satuan Pendidikan (Kementerian Kesehatan, 2020), yaitu dilakukan pada semua ruangan, lantai, pegangan tangga, meja dan kursi, pegangan pintu masuk, toilet, wastafel, alat peraga dan peralatan laboratorium, alat-alat pendukung pembelajaran dan fasilitas umum lainnya, seperti mushola dan perpustakaan.

Kegiatan disinfeksi bertujuan untuk agar terlaksananya disinfeksi lingkungan dalam rangka pencegahan dan mengurangi penularan COVID19 melalui permukaan lingkungan yang terkontaminasi virus SAR-CoV-2 atau penularan melalui fomite (Kementerian Kesehatan, 2020; World Health Organization (WHO), 2020). Hasil pelaksanaan pengabdian masyarakat di Desa Mekarbakti (Shalahuddin et al., 2021), didapatkan bahwa masyarakat antusias membantu kegiatan penyemprotan dan memiliki keyakinan bahwa kegiatan tersebut mampu untuk mencegah wabah COVID-19 dan berharap wabah COVID-19 segera berakhir.

SAR-CoV-2 termasuk dalam virus dengan lapisan lipid luar yang sangat rentan terhadap disinfektan (World Health Organization (WHO), 2020), dengan dilakukan penyemprotan disinfektan pada area di seluruh kampus dapat membuat virus SAR-CoV-2 mati, sehingga dapat mencegah transmisi penularan COVID-19. Berdasarkan beberapa penelitian didapatkan bahwa viabilitas virus SAR-CoV-2 pada kain dan kayu selama 2 hari, pada kaca selama 2 hari, 4 hari pada plastik dan stainless steel (World Health Organization (WHO), 2020). 


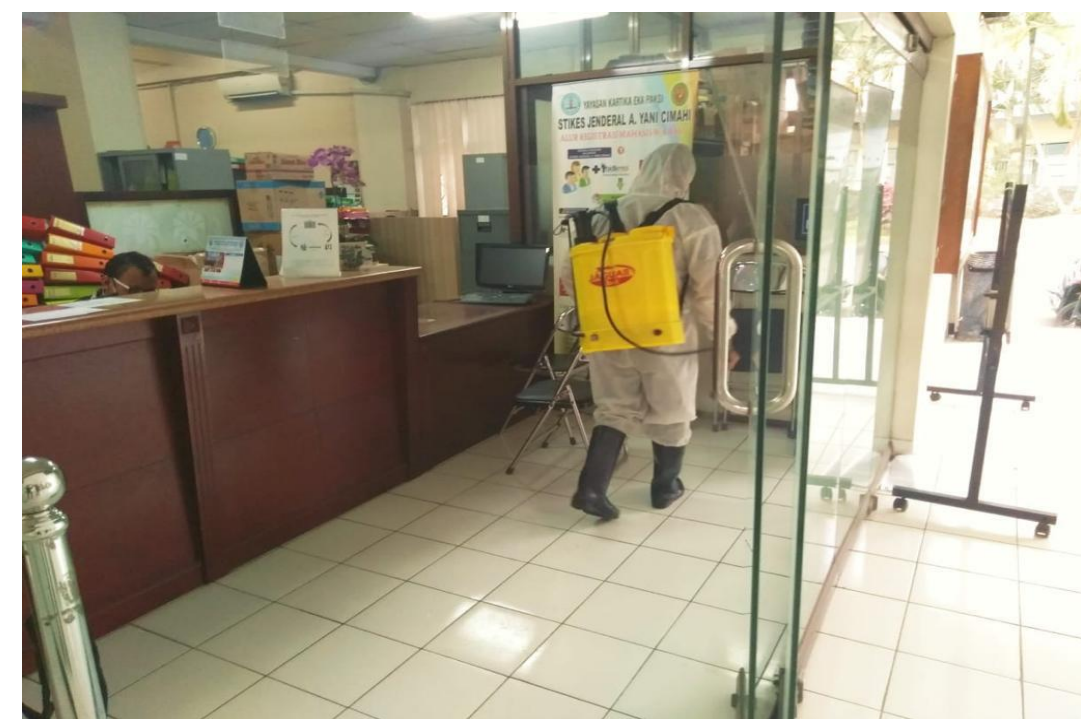

Gambar 3. Pelaksanaan Disinfeksi di Lingkungan Stikes A. Yani Cimahi

C. Partisipasi Relawan Rapid Diagnostic Test (RDT) antibodi COVID-19 Cluster Lembang Bandung

Peserta tim relawan Rapid Test COVID-19 Cluster lembang dari Stikes Jenderal Achmad Yani Cimahi sebanyak 19 orang mahasiswa dan 5 orang dosen pembimbing. Kegiatan Rapid Test Diagnostic (RTD) antibodi COVID19 Cluster Lembang dilaksanakan selama 4 (empat) hari, yaitu pada tanggal 30 - 31 Maret 2020, tanggal 01 dan 03 April 2020.

Lokasi pelaksanaan Rapid Test Diagnostic (RTD) antibodi COVID-19 Cluster Lembang:

a. Pengambilan sampel darah di laksanakan di GBI (Gereja Bethel Indonesia) Kota Bandung Jalan Aruna No. 19 Husen Sastranegara, Kecamatan Cicendo, Kota Bandung, Jawa Barat

b. Pemeriksaan sampel dilaksanakan di Laboratorium Kesehatan Daerah Kota Bandung, Pasteur, Kecamatan Sukajadi Kota Bandung, Jawa Barat dan Laboratorium Kesehatan Daerah Propinsi Jawa Barat, Jalan Sederhana No 3-5 Pasteur, Kecamatan Sukajadi Kota Bandung, Jawa Barat.

Kegiatan yang dilakukan oleh tim relawan Rapid Test Diagnostic (RTD) antibodi COVID-19 Cluster Lembang, diantaranya adalah sebagai berikut:

a. Pengambilan sampel darah

Pengambilan sampel darah pada peserta Rapid Test Diagnostic (RTD) antibodi melalui vena, pelaksanaan pengambilan darah menggunakan APD (Alat pelindung Diri) lengkap sesuai dengan standar WHO yaitu berupa Cover All Jumpsuits atau baju Hazmat (hazardous materials), penutup kepala, pelindung wajah (face shield), pelindung mata (goggle), masker N95, sarung tangan karet steril sekali pakai, sepatu dan pelindung kaki (cover shoes) (Gugus Tugas Percepatan Penanganan COVID-19, 2020).

b. Pengiriman sampel darah (Runner)

Sampel darah dari peserta rapid test yang telah di tempatkan pada tabung diserahkan ke petugas kurir untuk dikirim ke tempat pemeriksaan sampel yaitu Laboratorium Kesehatan Daerah yang telah di tunjuk. 
c. Pemeriksaan sampel darah

Tim sukarelawan membantu pelaksanaan pemeriksaan sampel darah dengan menggunakan APD (Alat pelindung Diri) lengkap sesuai dengan standar WHO yaitu berupa Cover All Jumpsuits atau baju Hazmat (hazardous materials), penutup kepala, pelindung wajah (face shield), pelindung mata (goggle), sarung tangan karet steril sekali pakai, sepatu dan pelindung kaki (cover shoes) (Gugus Tugas Percepatan Penanganan COVID-19, 2020).

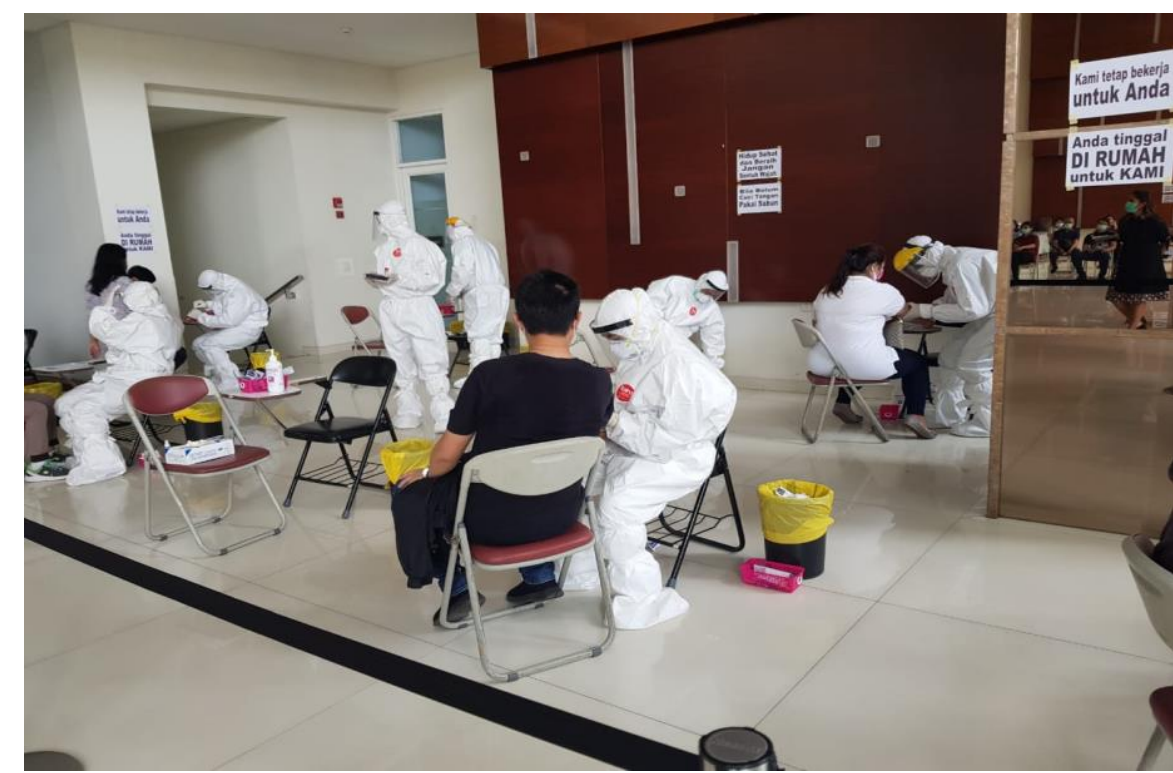

Gambar 4. Tim Relawan Rapid Test Cluster Lembang Bandung

Pada pandemik COVID-19 alat tes cepat (rapid test) banyak digunakan, karena hanya membutuhkan waktu 15 - 30 menit untuk dapat membaca hasil. Ada 2 jenis tes cepat untuk COVID-19, yaitu Rapid Test Diagnostic (RTD) antibodi dan Rapid Test Diagnostic (RTD) antigen. Rapid Diagnostic Test (RDT) antibodi COVID-19, berfungsi untuk mendeteksi adanya antibodi dari sampel darah atau serum. Antibodi dihasilkan oleh tubuh dalam waktu beberapa hari setelah terinfeksi virus (Halmar et al., 2020).

d. Partisipasi Relawan Check Point dalam pelaksanaan PSBB di Kota Bandung

Pengiriman tim sukarelawan di Check Point PSBB dilaksanakan selama 3 (tiga) periode PSBB, yaitu:

a. Tim relawan check point 1 PSBB Kota Bandung pada tanggal 02-05 Mei 2020, diikuti sebanyak 14 mahasiswa.

b. Tim relawan check point 2 PSBB Kota Bandung pada tanggal 08-19 Mei 2020 diikuti sebanyak 11 mahasiswa

c. Tim relawan check point 3 PSBB Kota Bandung pada tanggal 20 - 29 Mei 2020 diikuti sebanyak 8 mahasiswa 


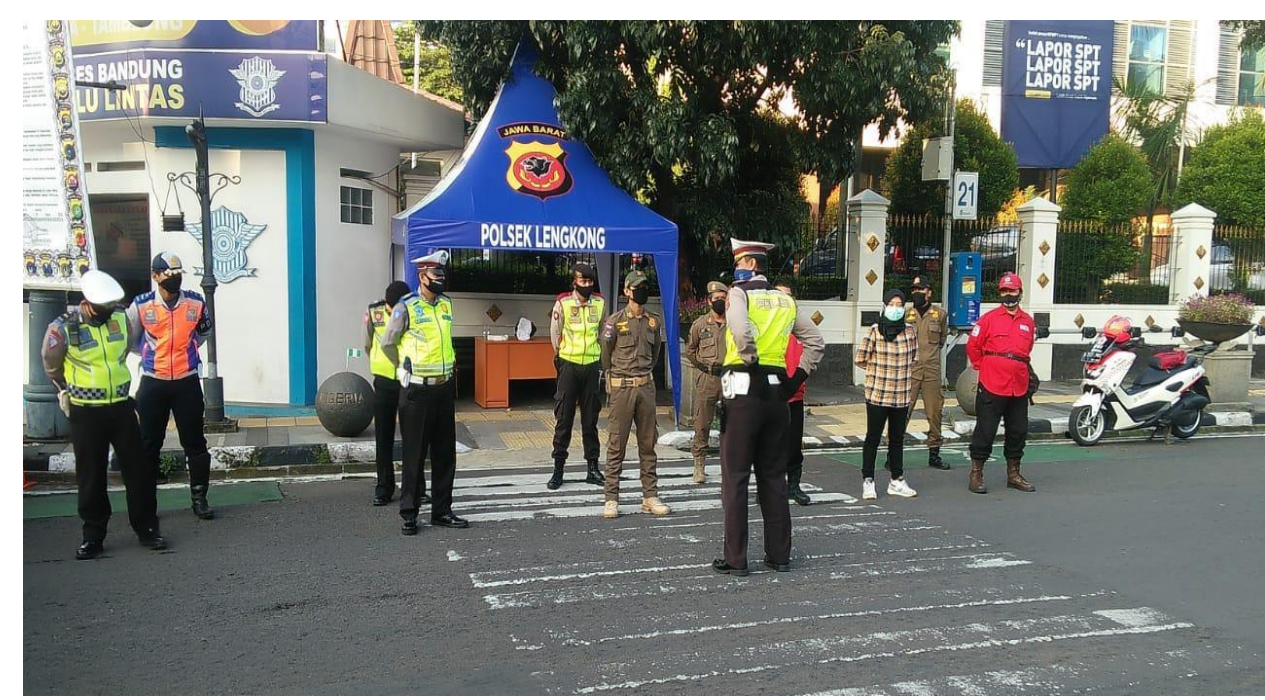

Gambar 5. Tim Relawan Check Point PSBB Kota Bandung

Pertimbangan dilaksanakannya PSBB (Pembatasan Sosial Berskala Besar) dalam rangka Percepatan Penanganan Coronavirus Disease (COVID19) (Karyono et al., 2020; Peraturan Pemerintah RI, 2020) adalah:

a. Penyebaran COVID-19 dengan jumlah kasus dan/atau jumlah kematian telah meningkat dan meluas lintas wilayah dan lintas negara dan berdampak pada aspek politik, ekonomi, sosial, budaya, pertahanan dan keamanan, serta kesejahteraan masyarakat di Indonesia;

b. Dampak penyebaran COVID-19 telah mengakibatkan terjadi keadaan tertentu sehingga perlu dilakukan upaya penanggulangan, salah satunya dengan tindakan pembatasan sosial berskala besar;

Tujuan PSBB yaitu memungkinkan pemerintah daerah membatasi pergerakan orang dan barang masuk dan keluar dari daerah masingmasing kecuali telah mendapat izin. Pembatasan kegiatan yang dilakukan meliputi penutupan tempat-tempat pembelanjaan, tempat wisata, penggunaaan mekanisme bekerja dari rumah (Work from Home/WFH), peliburan sekolah dan melakukan pembelajaran secara online (metode daring atau dalam jaringan), pembatasan kegiatan keagamaan, dan/atau pembatasan kegiatan di tempat atau fasilitas umum (Karyono et al., 2020; Peraturan Pemerintah RI, 2020).

Operasi Check Point ialah titik untuk memastikan PSBB berlangsung sesuai aturan yang berlaku, termasuk bagi pengendara sepeda motor, mobil, serta angkutan umum agar berkendara sesuai regulasi selama PSBB, di tiap Pos Check Point, terdiri dari tim gabungan dari TNI, Polri, Dinas Perhubungan, Satpol PP, Dinas Kesehatan, serta beberapa relawan akan memberhentikan kendaraan yang datang untuk melakukan pemeriksaan.

Operasi check point juga melakukan pemeriksaan penggunaan masker bagi pengendara bermotor, sehingga memastikan semua pengendara memakai masker pada saat berkendara. Masker merupakan salah satu alat pelindung diri (APD) yang berfungsi untuk melindungi pengguna dari terhirupnya partikel udara dan dapat melindungi kesehatan saluran pernafasan. Penggunaan masker dapat mengurangi infeksi penyakit yang dapat ditularkan melalui seluran pernafasan seperti virus influenza, coronavirus pada manusia dengan mencegah terjadinya penyebaran 
percikan ludah yang dapat ditransmisikan dari satu orang ke orang lain (Fernalia et al., 2021).

e. Donasi Sembako kepada masyarakat Terdampak COVID-19

Pembagian sembako untuk masyarakat terdampak pandemi COVID-19 dilaksanakan pada hari Jumat, tanggal 26 Juni 2020 pukul 08.00 - 11.00 WIB. Pembagian sembako di laksanakan di area kampus Stikes Jenderal Achmad Yani Cimahi dengan tetap menerapkan protokol kesehatan secara ketat bagi semua penerima donasi dan petugas yang memberikan donasi.

Tujuan pemberian donasi sembako adalah dalam rangka meringankan beban ekonomi masyarakat yang terdampak pada masa Pandemi COVID19, terutama berkaitan dengan penemuhan kebutuhan dasar sehari-hari, meliputi: Beras, minyak goreng, mie instan dll.

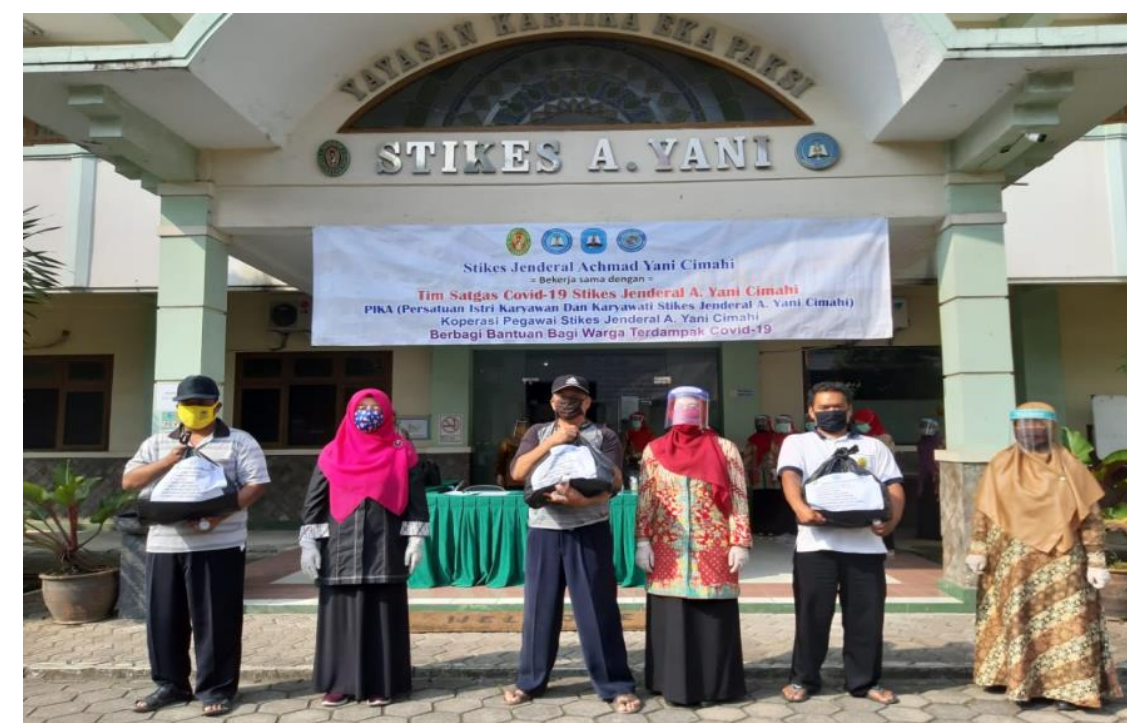

Gambar 6. Pemberian Sembako pada Masyarakat terdampak COVID-19

f. Pemberian Donasi APD (Alat Pelindung Diri) pada fasilitas pelayanan Kesehatan di wilayah Kota Cimahi dan Kota Bandung

Donasi APD (Alat Pelindung Diri) diberikan oleh Stikes Jenderal Achmad Yani Cimahi, diantaranya adalah: Rumah Sakit Umum Cibabat Kota Cimahi, Rumah Sakit Dustira, Rumah Sakit Umum Daerah Soreang Kabupaten Bandung dan Rumah Sakit Al Islam Kota Bandung, dan UPT Puskesmas Puter Kota Bandung.

Alat pelindung diri (APD) yang di donasikan ke beberapa tempat pelayanan kesehatan meliputi: masker medis dan Cover All Jumpsuits atau baju Hazmat (hazardous materials). 


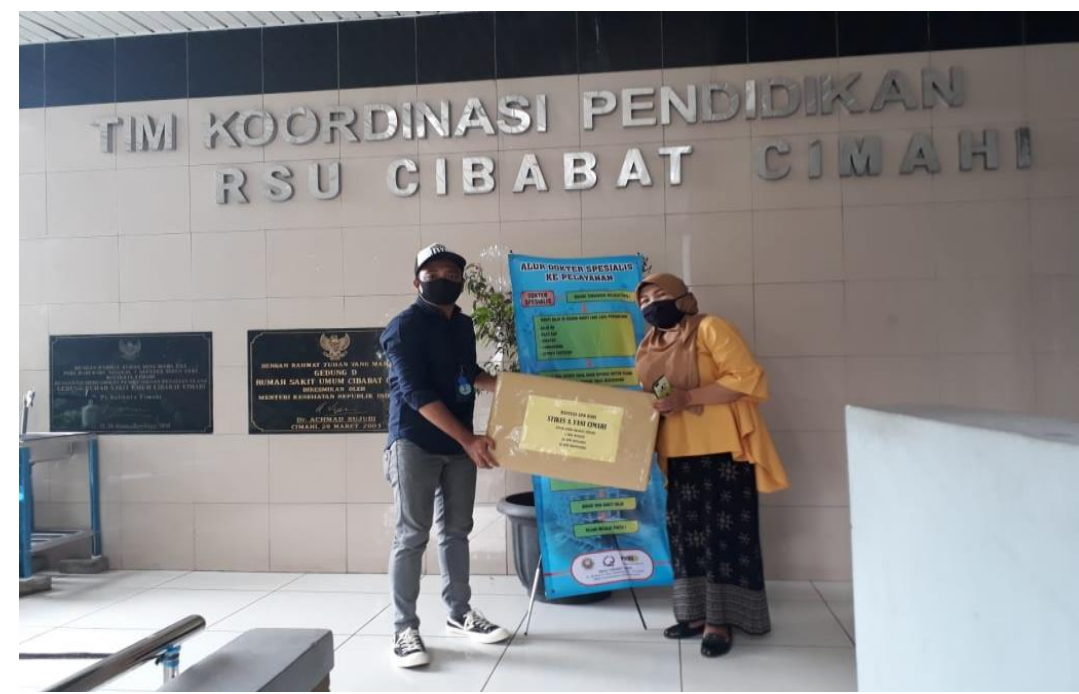

Gambar 7. Donasi Alat Pelindung Diri

g. Pelaksanaan Rapid Test Diagnostic (RTD) antibodi dan Rapid Test Diagnostic (RTD) antigen kepada mahasiswa, Dosen dan karyawan

Rapid Test Diagnostic (RTD) antibodi dan Rapid Test Diagnostic (RTD) antigen dilaksanakan secara periodik kepada mahasiswa, dosen dan karyawan. Kegiatan ini bertujuan untuk screening dan mendeteksi adanya paparan penyakit COVID-19 di lingkungan Stikes Achmad Yani Cimahi.

RTD antibodi dilakukan untuk mendeteksi adanya antibodi yang berada di dalam darah setelah adanya paparan antigen dari virus COVID19. RDT antibodi tidak dapat digunakan untuk diagnosis klinis penyakit COVID-19, namum dapat membantu dalam surveilans penyakit dan deteksi dini adanya infeksi (Yanti et al., 2020).

Pemeriksanaan RDT antigen dilakukan dengan mendeteksi presensi nucleoprotein antigen dan SARS-CoV-2 pada sampel yang berasal dari saluran pernafasan. Antigen COVID-19 hanya bisa dideteksi saat virus aktif bereplikasi, sehingga tes RDT antigen ini paling baik digunakan pada awal infeksi COVID-19 pada fase akut (Yanti et al., 2020).

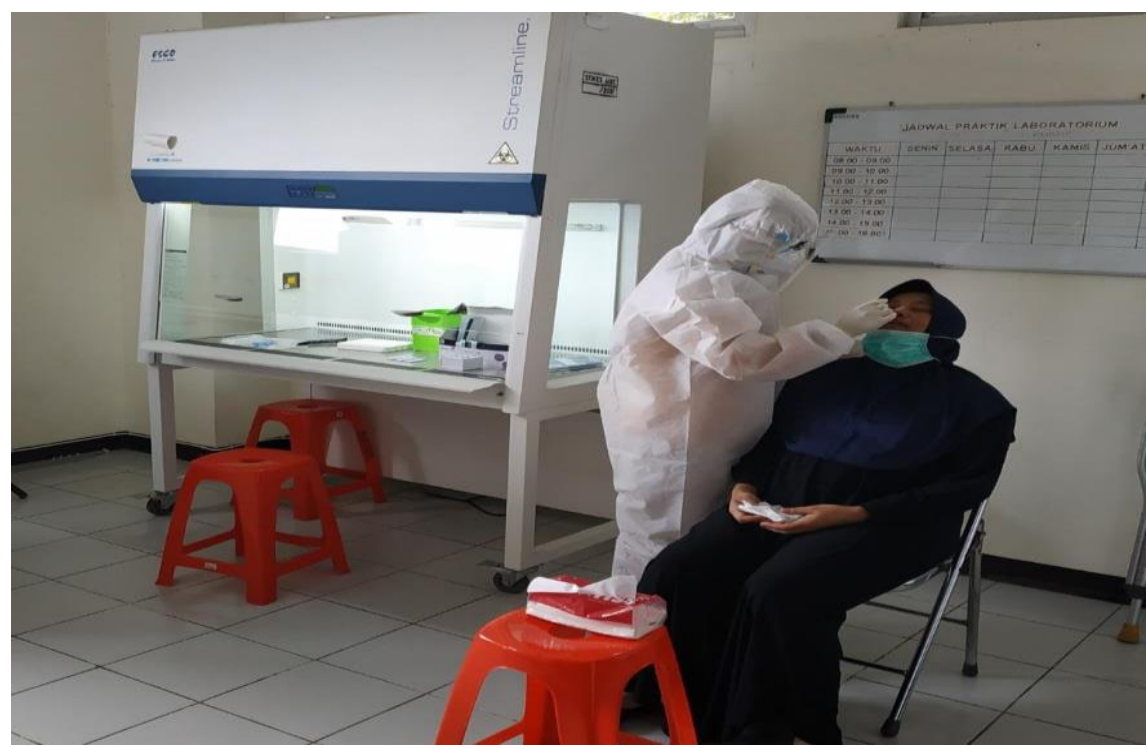

Gambar 8. Pengambilan Sampel RTD Antigen 
RDT antibodi dan RDT antigen dilakukan untuk persiapan pelaksanaan suatu kegiatan terprogram yang melibatkan personil lebih dari 30 orang secara offline seperti perkuliahan tatap muka untuk praktikum laboratorium, persiapan pelaksanaan kegiatan akad janji mahasiswa, persiapan pelaksanaan wisuda dll. RDT antibodi dan RDT antigen juga dilakukan apabila dilaporkan adanya paparan atau kontak erat dengan penderita COVID-19.

Apabila dalam pelaksanaan kegiatan Screening COVID-19 menggunakan RDT antibodi ditemukan adanya hasil yang reaktif, atau hasil pemeriksaan RDT antigen ditemukan hasil positif, disarankan untuk dilanjutkan melakukan pemeriksaan Swab PCR (Polymerase Chain Reaction) agar diketahui apakah menderita COVID-19 atau penyakit lain. Selanjutnya apabila hasil swab PCR dinyatakan positif menderita COVID19 diwajibkan untuk melakukan isolasi mandiri sesuai ketentuan berdasarkan Pedoman Pencegahan dan Pengendalian Coronavirus Disease (COVID-19) Revisi 5, serta dilakukan pemantaua kesehatan oleh petugas Kesehatan yang ditunjuk oleh Tim Satgas COVID-19 di Stikes Achmad yani Cimahi (Kementerian Kesehatan RI, 2020).

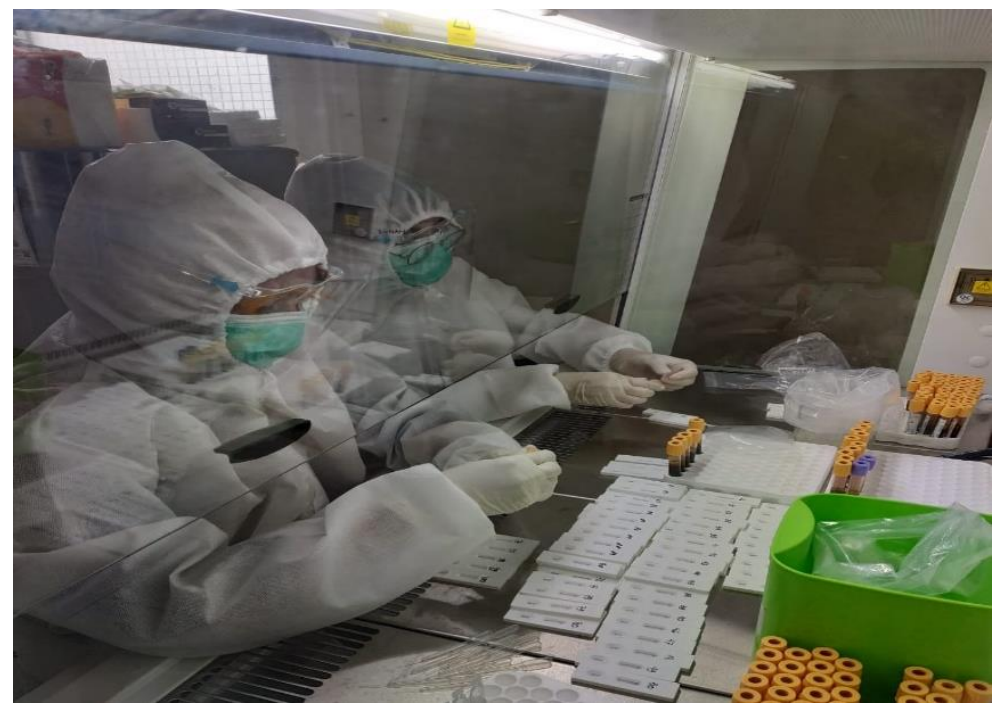

Gambar 9. Pemeriksaan Sampel RTD Antigen

i. Pelaksanaan vaksinasi bagi tenaga kesehatan dan pengiriman relawan vaskinator dalam gebyar Vaksin COVID-19 di Jawa Barat

Stikes Achmad Yani ikut serta dalam kegiatan gebyar vaksin COVID19 yang diselenggarakan oleh Rumah Sakit Hasan Sadikin (RSHS) Bandung bekerjasama dengan PPNI (persatuan Perawat Nasional Indonesia) Propinsi Jawa Barat. Kegiatan Gebyar Vaksin COVID-19 diantaranya adalah pelaksanaan vaksin pada tenaga kesehatan. 


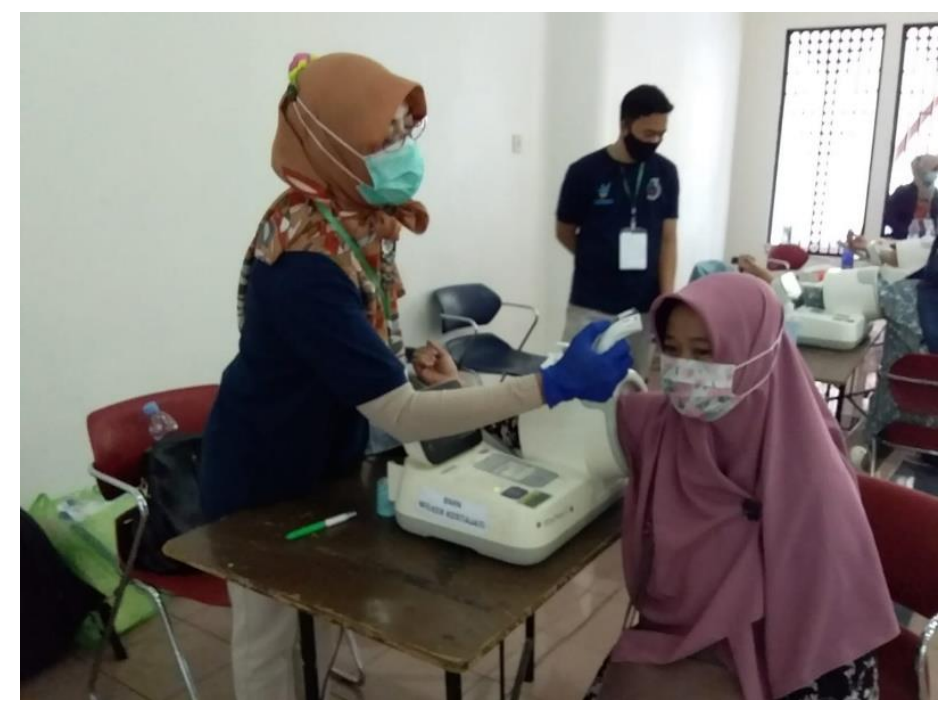

Gambar 10. Screening Calon Penerima Vaksin COVID-19

Stikes Achmad Yani Cimahi mengirimkan sebanyak 140 peserta calon penerima vaksin yang terdiri dari: dosen, mahasiswa dan karyawan. Pelaksanaan Vaksin COVID-19 pertama pada tanggal 3-4 Februari 2021 dan Vaksin kedua pada tanggal 17-18 Februari 2021.

Stikes Achmad Yani Cimahi mengirimkan tim relawan petugas vaksinator sebanyak 5 orang yang terdiri dari Tim Dosen Program Studi Keperawatan dan Mahasiswa dan bertugas untuk membantu dalam pelaksanaan vaksin COVID-19.

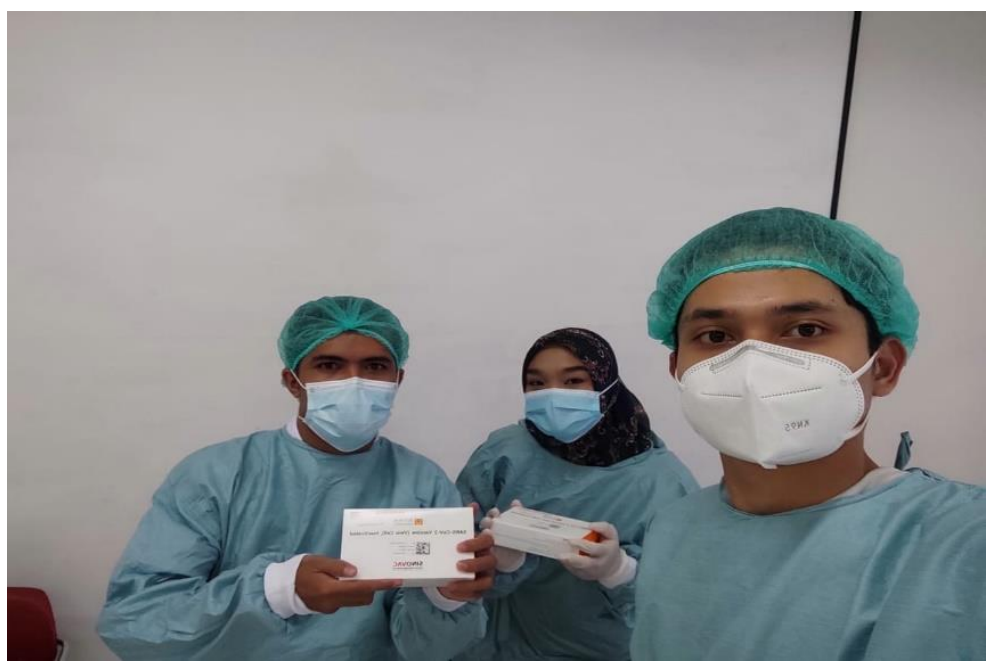

Gambar 11. Relawan Vaksinator Gebyar Vaksin COVID-19

\section{KESIMPULAN DAN SARAN}

Kegiatan yang dilakukan Stikes Achmad Yani Cimahi dalam berbagai kegiatan yang berkaitan dengan pencegahan, deteksi dini penyakit, dan penanggulangan COVID-19 diharapkan dapat memberikan kontribusi dalam rangka pencegahan penularan penyakit, pengendalian dan dapat memutus mata rantai penyebaran penyakit COVID-19 di masyarakat.

Disarankan hendaknya kegiatan ini dapat dilaksanakan secara kontinu sampai dengan berakhirnya masa pandemik COVID-19. 


\section{DAFTAR PUSTAKA}

Dirjen Pencegahan dan Pengendalian penyakit. (2021). Petunjuk Teknis Pelaksanaan Vaksinasi dalam rangka Penanggulangan Pandemi COVID-19.

Fernalia, Pawiliyah, Rahmawati, I., Juksen, L., Sanisahhuri, \& Rizal, S. (2021). Sosialisasi Penggunaan Masker dan Pembagian Masker Kepada Warga untuk Pencegahan COVID-19 di Pasar Tradisional Kota Bengkulu. Jurnal Kreatifitas Pengabdian Kepada Masyarakat (PKM), 4(1), 10-17. https://doi.org/10.33024/jkpm.v4i1.3577

Gugus Tugas Percepatan Penanganan COVID-19. (2020). Standar Alat Pelindung Diri (APD) untuk Penanganan COVID-19 di Indonesia.

Halmar, H. F., Febrianti, N., Kurnyata, M., \& Kada, R. (2020). Pemeriksaan Diagnostik COVID-19: Studi Literatur. Jurnal Keperawatan Muhammadiyah, 5(1). http://dx.doi.org/10.30651/jkm.v5i1.4758

Karyono, Rohadin, \& Indriyani, D. (2020). Penanganan dan Pencegahan Pandemi Wabah Virus Corona (COVID-19 ). Jurnal Kolaborasi Resolusi Konflik, 2(2), 164-173. https://doi.org/10.24198/jkrk.v2i2.29127.g13932

Kementerian Kesehatan. (2020). Panduan Desinfeksi dalam Rangka Pencegahan Penularan COVID-19.

Kementerian Kesehatan RI. (2020). Pedoman Pencegahan dan Pengendalian Coronavirus Disease (COVID-19).

Keputusan Presiden RI. (2020). Penetapan Bencana Nonalam Penyebaran Corona Virus Disease 2019 (COVID-19) Sebagai Bencana Nasional.

Peraturan Pemerintah RI. (2020). Pembatasan Sosial Berskala Besar dalam rangka Percepatan Penanganan Corona Virus Disease 2019 (COVID-19).

Perkembangan COVID-19 di Kota Cimahi, (2020).

Shalahuddin, I., Rosidin, U., Purnama, D., Keperawatan, F., Padjadjaran, U., Garut, K., Keperawatan, F., Padjadjaran, U., Garut, K., Keperawatan, F., Padjadjaran, U., \& Garut, K. (2021). Edukasi pada Mayarakat Desa Mekarbakti Kecamatan Pamulihan Kabupaten Sumedang tentang Pentingnya Upaya-upaya Pencegahan Penularan Penyakit COVID-19. Jurnal Kreatifitas Pengabdian Kepada Masyarakat (PKM), 4(1), 1-9. https://doi.org/10.33024/jkpm.v4i1.3594

Tong, Y., Ph, D., Ren, R., Med, M., Leung, K. S. M., Ph, D., Lau, E. H. Y., Ph, D., Wong, J. Y., Ph, D., Xing, X., Ph, D., Xiang, N., Med, M., Wu, Y., Sc, M., Li, C., Chen, Q., Sc, M., ... Med, M. (2020). Early Transmission Dynamics in Wuhan, China, of Novel Coronavirus-Infected Pneumonia. The New England Journal of Medicine, 382(15), 1199-1207. https: / /doi.org/10.1056/NEJMoa2001316

WHO. (2020). Coronavirus Disease (COVID-19) situation report.

World Health Organization (WHO). (2020). Pembersihan dan disinfeksi permukaan lingkungan dalam konteks COVID-19. 1-9.

Yanti, B., Ismida, F. D., Elsa, K., \& Sarah, S. (2020). Perbedaan uji diagnostik antigen, antibodi, RT-PCR dan tes cepat molekuler pada Coronavirus Disease 2019. Jurnal Kedokteran Syiah Kuala, 20(3), 172-177.

https://doi.org/10.24815/jks.v20i3.18719 